\title{
Sequestros e terrorismo de Estado no Brasil: casos de resistência revolucionária
}

Kidnappings and state terrorism in Brazil: cases of revolutionary resistance

\author{
Carla Luciana Silva*
}

Resumo: Este artigo se insere no estudo das formas de resistência à Ditadura instaurada no Brasil em 1964. Busca, a partir de uma perspectiva crítica, reunir materiais e apresentar uma interpretação sobre a tática de sequestros das organizações armadas. O objetivo é problematizar o uso de sequestros como medida de pressão e luta pelos movimentos de resistência à Ditadura, entendendo-os como medida defensiva. Fazemos uma descrição dos sequestros, trazendo alguns relatos e avaliações de envolvidos. Aprofundamos o caso do sequestro do embaixador suíço, com desfecho em 11/1/1971, e que possibilitou o resgate de 70 presos. Sobre este caso acessamos a documentação diplomática trocada entre a Embaixada brasileira e o governo chileno. Este foi o último sequestro e o que mais levou a libertação de presos. A hipótese é que, embora as ousadas ações de sequestro tenham sido bem-sucedidas, elas trouxeram posteriormente dificuldades insolúveis para as organizações. Foram atos defensivos de resistência, que salvaram vidas, mas que geraram severa repressão e desorganização aos envolvidos.

Palavras chave: Sequestros, ditadura, resistência, organizações armadas

\begin{abstract}
This article is part of a study of the way of resistance against to the dictatorship established in Brazil in 1964. From a critical perspective, it seeks to gather materials and present an interpretation of the kidnapping tactics of armed organizations. The purpose is to problematize the use of kidnappings as a measure of pressure and fight for the movements of resistance against to the dictatorship, understanding them as a defensive measure. We give a description of the abductions, bringing some reports and evaluations of those involved. We deep into the case of the kidnapping of the Swiss ambassador, which ended on January 11, 1971, which enabled the rescue of 70 prisoners. In this case we access the diplomatic documentation exchanged between the Brazilian Embassy and the Chilean government. This was the last kidnapping and the one that most led to the release of prisoners. The hypothesis is that while the bold kidnapping actions were successful, they subsequently brought
\end{abstract}

\footnotetext{
* Brasileira, Docente da Graduação e da Pós Graduação em História da UNIVERSIDADE Estadual do Oeste do Paraná- UNIOESTE. Pós Doutorado na Universidade Nova de Lisboa. Esta pesquisa é financiada pela Fundação Araucária (2016-2019). carlalusi@gmail.com
} 
insoluble difficulties to organizations. These were defensive acts of resistance that saved lives but generated severe repression and disorganization for those involved.

Key Words: kidnapping of diplomats, dictatoryship, resitance, armed organizations

Recibido: 25 junio 2019 Aceptado: 22 septiembre 2019

Desde 1964 o Brasil viveu uma Ditadura que, engendrada por setores empresariais, era sustentada pelas Forças Armadas que compunham o governo e foram sistematicamente ocupando cargos em todas instâncias governamentais. A partir de 1968, com o Ato Institucional 5, os direitos civis foram drasticamente interrompidos. Duas características da Ditadura no Brasil se destacam: a institucionalidade, que regulamentava através de leis seus atos discricionários; a mudança de presidentes militares, o que contribuía para manter uma sensação de democracia na população. No período que abordamos nesse artigo temos o governo de Garrastazu Medici, que também demarcaria o chamado "milagre Econômico". No seu governo foram incrementadas técnicas de repressão como a criação de um órgão específico para esse fim, o DOI-CODI. Já eram correntes a perseguição a militantes e assassinatos em emboscadas e perseguições, como atesta o essencial estudo realizado pela Comissão de Familiares de Mortos e Desaparecidos ${ }^{1}$, que atesta que os anos que se seguiriam aos sequestros seriam ainda mais atrozes quanto à repressão.

\section{O problema historiográfico}

Desconhecemos que existam estudos aprofundados sobre o tema deste artigo, ou seja, que problematizem a utilização de sequestros por grupos de ação armada durante a Ditadura no Brasil. O tema aparece de forma secundária em diversos trabalhos, mas não foi problematizado enquanto tal. Nossa perspectiva propõe inserir os sequestros no âmbito das ações de resistência da ditadura. Ou seja, não os entendemos como avanço de uma guerra revolucionária, e sim como um momento defensivo que foi eficaz, com claros e restritos limites. Por isso entendemos necessário restringir o debate historiográfico a esse problema: a ação revolucionária no caso dos sequestros entendida como um ato de resistência, no âmbito do momento histórico em que ocorreu.

Esse debate é marcado pela posição de Jacob Gorender, que entendeu o período de 1964 como um real momento de luta pré-revolucionária, "o auge da luta de classes, em que se pôs em xeque a estabilidade institucional da ordem burguesa" 2. Foi, para ele, um momento de fracasso, onde "houve a possibilidade de vencer, mas foi perdida". Já Marcelo

\footnotetext{
${ }^{1}$ Comissão de Familiares de Mortos e Desaparecidos Políticos - IEVE. Dossiê Ditadura: mortos e desaparecidos no Brasil. $2^{a}$ ed. São Paulo, Imprensa Oficial, 2009, 772p.

2 Jacob Gorender, Combate nas trevas. São Paulo, Ática, 1998. P. 73.
} 
Ridenti $^{3}$ indica que a resistência foi o caminho possível naquele momento, para além da vontade das organizações, que se entendiam como revolucionárias, que acreditavam travar a "guerra revolucionária", mas que acabaram "intimidados, perseguidos, presos, seviciados ou mortos pelo regime" 4 . Disso concluímos, sem qualquer julgamento moral, que embora estivessem imbuídos de uma vontade revolucionária, as dificuldades levaram a que os sequestros fossem defensivos.

O problema da "resistência" foi trazida por uma discussão historiográfica que buscou ver os atos da esquerda armada apenas como erros de opção, acusando-a inclusive de usurpar da resistência revolucionária ${ }^{5}$ no âmbito da redemocratização ${ }^{6}$. $O$ fato é que

se constituiu no Brasil um regime militar e civil que duraria mais de vinte anos, e as ações das esquerdas armadas transcorreram todas na vigência desse regime, de modo que são impensáveis fora do quadro concreto de combate à ditadura, ainda que o projeto das organizações marxistas não se restringissem a derrubá-lo. ${ }^{7}$

É dentro de um campo de tensões, resistência e clandestinidade, que os grupos armados brasileiros desencadeiam os sequestros de diplomatas. Nossa hipótese é de que os casos analisados tiveram caráter político, de resolução de problemas imediatos, com graves consequências aos envolvidos e à sequência das lutas. Não foram atos de propaganda revolucionária, diferentemente de outros atos realizados pelos grupos (como quando em 15/8/1969 a ALN tomou a rádio a tomada dos transmissores de radiodifusão em São Paulo, apenas para citar um exemplo). A ditadura logo proibiu a difusão de manifestos em sequestros, buscando diminuir o apoio popular a eles.

Também não foram, como princípio, atos terroristas, pois eles tinham objetivos concretos, políticos: previam a troca de pessoas que eram vítimas da Ditadura Não propuseram em nenhum caso ganhos pecuniários. Mesmo em caso de maior conflito de negociação, no caso do Embaixador Suíço, os militantes evitaram a solução de matar o sequestrado, pois o que prevaleceu foi a lógica política. Isso não isenta os militantes do cargo da violência revolucionária, já que duas mortes ${ }^{8}$ e ferimentos ocorreram nos atos de sequestro. Os atos em si são rememorados em memórias que mostram a fragilidade das organizações, com peculiaridades surpreendentes como o carro que iria ser usado no sequestro ser recolhido por multas, ou o sequestrador "se ambientar" no local de cativeiro jogando futebol com a população vizinha. Mas o fato é que se tratou de momentos tensos, que acabaram alcançando o objetivo imediato, mas que não comporiam um plano estratégico de lutas.

\footnotetext{
${ }^{3}$ Marcelo Ridenti, O fantasma da Revolução brasileira. 2a ed. São Paulo, EDUNESP, 2010.

4Idem, p. 265.

${ }^{5}$ Este tema está discutido em Lucileide Costa Cardoso. Revolução e resistência: historiografia e luta armada no Brasil. Revista da FLUP, Porto, IV Série, vol. 4, 2014.

6 Este debate é discutido pelos autores que pautam o tema do "revisionismo" sobre a ditadura (MELO e SENA $\mathrm{Jr}$, ), e tem como resultado a diminuição da importância da luta de resistência.

${ }^{7}$ Marcelo Ridenti, Esquerdas armadas urbanas, In: RIDENTI, M e REIS, D. (Orgs) História do marxismo no Brasil, Campinas, EDUNICAMP, 2007. P. 106.

${ }^{8}$ Nos casos de sequestro do embaixador alemão e do suíço.
} 


\section{Guerra revolucionária institucionalizada}

Um dos problemas centrais que envolveu as esquerdas latino-americanas no contexto das resistências às ditaduras se relaciona à violência revolucionária, e nesse sentido, os conflitos entre revolução e resistência já encontram algum debate historiográfico, mas o debate sobre as formas do uso da violência foi incipiente no que toca ao caso brasileiro. Embora a sociedade brasileira da primeira metade do século $X X$ estivesse acostumada às disputas políticas e discursivas em torno dos termos revolução, golpe, questão social, etc, o problema da legitimidade da violência revolucionária não se tornou alvo de debate. $\mathrm{O}$ anticomunismo, dessa forma, foi o grande fio condutor da imaginação social no que diz respeito à luta de classes ao longo do século XX. Não se deu voz ao discurso revolucionário, ao contrário, ele foi sumariamente excluído da política.

Os militares, com apoio civil, pautaram o tema da Guerra Revolucionária e da ação subversiva. Eles se apropriaram de uma elaboração de esquerda a partir das experiências de combate a guerrilhas, sobretudo o caso argelino, e passaram, preventivamente, a alardear a existência de uma Guerra revolucionária no Brasil. Como esse era originalmente um discurso de esquerda, os movimentos armados sempre tiveram dificuldades de avaliar as forças em jogo nessa guerra.

É a partir desse pano de fundo que vemos como as questões que envolvem os sequestros realizados por grupos armados no Brasil são enquadradas em leis que se adaptam a combater quaisquer avanços de luta revolucionária. A Lei de Segurança Nacional, através do Decreto-Lei n ${ }^{\circ}$ 314, de 13 de Março de 1967 qualificava os sequestros no seu artigo 25, associando esse ato a uma série de outros crimes:

Artigo 25: "Praticar massacre, devastação, saque, roubo, sequestro, incêndio ou depredação, atentado pessoal, ato de sabotagem ou terrorismo; impedir ou dificultar o funcionamento de serviços essenciais administrados pelo Estado ou mediante concessão ou autorização.

Com um escudo institucional, próprio da Ditadura brasileira, se mantinha uma aparência democrática, o governo da ditadura brasileira traz uma resposta contumaz: cria a figura do banimento, ou seja, uma definição de "não-cidadania" a todos os sujeitos brasileiros que deixariam o Brasil nas trocas por diplomatas e que com esse decreto deixam de gozar de direitos civis, a partir de um ato dos Tribunais Militares. Diz o Ato Institucional n. 13, de 5/9/1969 que: “Art. $1^{\circ}$ - O Poder Executivo poderá (...) banir do território nacional o brasileiro que, comprovadamente, se tornar inconveniente, nocivo ou perigoso à segurança nacional". Essa seria a resposta institucional, para as pessoas envolvidas nas trocas as quais se viu obrigada a realizar. Na prática, associa-se a LSN ao Ato Institucional, permeado pela lógica do Terrorismo de Estado.

Se não localizamos uma teoria dos grupos em luta sobre os sequestros, entendemos que essa tática não pode ser elaborada como estratégia. Foram intensos os estudos promovidos pelas Forças Armadas no sentido de entender e combater a "Guerra 
Revolucionária"9, sobretudo a partir da influência francesa de combates na Argélia ${ }^{10}$. Há um reordenamento internacional da repressão, mas igualmente, aumentam as dificuldades concretas para aqueles que seguiriam no Brasil após os sequestros. Por isso buscamos aqui apontar o contexto mais amplo dos sequestros, para entende-lo como tática revolucionária que no caso brasileiro acabou tendo um papel defensivo.

Observe-se por exemplo, o caso do sequestro do embaixador japonês: era imensa a urgência de libertar um prisioneiro, Nobuo Okushi, que voltava de Cuba e conhecia o esquema de treinamentos do Vale da Ribeira. Foi com o sentido defensivo que o mesmo foi realizado, e por isso o caso teve um desfecho relâmpago, e salvou da prisão apenas cinco pessoas: "dentro de 24 horas, cinco presos políticos, juntamente com os três filhos de um prisioneiro, foram levados ao México de avião em troca do cônsul japonês, são e salvo"11. Não havia espaço para negociações e avanços, o que era necessário era impedir que o preso acabasse revelando segredos na atroz tortura que estava sofrendo.

Não encontramos na literatura uma definição clara do que foram os sequestros e seu papel para a esquerda. Esses fatos aparecem via de regra no nível do fato consumado e das memórias dos militantes que deles participaram, evidentemente ressaltando suas dificuldades. É muito comum que os sobreviventes quando se encontram na atualidade se reconheçam por ter "saído no suíço", ou "saído no alemão", forma de identificar que foram trocados nos respectivos sequestros, marca de sua sobrevivência.

Observe-se que os sequestros levados a cabo pelo Terrorismo de Estado jamais foram contabilizados e problematizados enquanto tal. Foram sequestros ou raptos que de certa forma se perderam no absoluto da violência que deles resultavam: a prisão, a tortura, a morte, o ocultamento de cadáver. O que se tornou predominante na literatura é a associação de sequestro com os raptos de diplomatas como medida de troca por prisioneiros e posterior libertação das pessoas que serviam de garantias, no caso, os diplomatas. Não há, nesses casos, repetição de fatos que ocorreriam em outras experiências de luta, como Uruguai ou Itália, pois nem se pede resgate em dinheiro nem se vai às últimas consequências com a morte do sequestrado. Foi, portanto, uma forma defensiva, de salvar vidas, mas que pouco contribuiu com o avanço da luta, embora possa ter tido um efeito imponderável, a criação de um mito do guerrilheiro herói, capaz de sequestrar o embaixador dos Estados Unidos, por exemplo. Mas esse aspecto embora apareça pontualmente em alguns relatos, não gerou um movimento popular de apoio à resistência armada.

No Manual do Guerrilheiro Urbano, o líder da ALN, Carlos Marighella definiu o sequestro como uma das ações desejadas para o guerrilheiro urbano. Entre várias opções em que legitimava a ação, destacamos: "O sequestro é usado para trocar ou libertar camaradas revolucionários aprisionados, ou para forçar a suspensão da tortura nas cadeias de uma ditadura militar"12. O texto de Marighella está em sintonia com a ideia de guerra

\footnotetext{
${ }^{9}$ Uma fonte que corrobora nessa tese é o compêndio "Noções básicas de Guerra Revolucionária", coletânea do Estado Maior do Exército, de 1963. Nele, diversos militares discutem táticas de guerrilha, caracterizam "o terror" e insistem na necessidade de realizar sólida formação dos agentes repressivos contra ela.

10 Jussaramar da Silva, As conexões repressivas no ConeSul (1960-90): Terrorismo de Estado em conexão Internacional, Tese de Doutorado em História, PUCSP, 2017

11 James Green, Revolucionário e gay, Rio de Janeiro, Civilização Brasileira, 2018, 144.

12 Carlos Marighella, Manual do Guerrilheiro Urbano, Folheto, 1969.
} 
revolucionária. Mas na prática, o próprio manual não trazia um estudo aprofundado de como essa tática poderia ser vitoriosa.

\section{Sequestros e ditaduras}

Vamos traçar um quadro geral dos sequestros, para focar mais especificamente no sequestro do embaixador suíço, que teve como resultado a troca por 70 prisioneiros que foram recebidos no Chile. A primeira parte traz fontes já conhecidas em sua maior parte, mas que reunidos nos fazem dimensionar os problemas em questão. Na segunda, avançamos com documentos que localizamos na pesquisa realizada diretamente no Ministério Exterior do Chile, em Santiago. Trazemos dados sobre as dificuldades que foram enfrentadas no campo diplomático e nas negociações.

O objetivo é problematizar o uso de sequestros como medida de pressão e luta pelos movimentos de resistência à Ditadura. Também recorreremos a relatos de pessoas envolvidas nos mesmos. A bibliografia é rica em trazer distintos relatos de pessoas que participaram direta ou indiretamente dos sequestros. São falas importantes, emotivas, participativas e muito importantes para o conhecimento histórico. Entendemos, como Enzo Traverso ${ }^{13}$, que os relatos contribuem para a memória como disputa política. Como aqui não podermos dar conta desses problemas, alguns textos biográficos serão aqui trazidos de forma complementar ao nosso argumento, pois entendemos que ampliar a discussão dos depoimentos nos obrigaria a discutir as opções de cada uma das organizações revolucionárias em questão, tarefa ainda inconclusa.

Escolher a vítima, organizar a ação, negociar, são processos tensos que nem sempre redundam em resultados positivos. No contexto da Ditadura brasileira, alguns sequestros foram muito bem-sucedidos, do ponto de vista da tática, da "recompensa", e também da manutenção da vida do sequestrado. ${ }^{14}$

A caça aos envolvidos foi atroz e se tornou impossível realizar novas ações já que a repressão foi implacável após os desfechos, buscando, prendendo e matando aqueles envolvidos nos sequestros, tema que em si merece maiores estudos. Outro problema era para onde os resgatados iriam após a libertação, e aqui entram as negociações diplomáticas. No caso do maior sequestro, foi essencial o envolvimento do governo socialista de Salvador Allende. A chancelaria chilena buscou amenizar o impacto do recebimento dos sequestrados, aventando possibilidades de dividir com outros países a responsabilidade e mesmo buscando facilitar a saída dos resgatados do seu país. Tinham clareza que muitos dos resgatados eram atuantes politicamente na resistência à ditadura no Brasil. As ondas de denúncia contra a tortura que se seguiram ao resgate colocavam o governo de Salvador Allende no foco da imprensa internacional. Do ponto de vista diplomático era uma grande tacada dos sequestradores, pois o Brasil precisava aceitar as imposições das embaixadas que tinham seus diplomatas ameaçados. Nisso constituiu a força dos sequestros que conseguiram salvar a vida de mais de 100 pessoas.

13 Enzo Traverso, O passado modos de usar, Lisboa, Unipop, 2012.

14 No momento do rapto do embaixador suíço ocorreu a morte do agente de segurança Helio de Carvalho Araujo e no do sequestro do embaixador alemão o policial Irlando de Souza Regis, além de outros com ferimentos graves. 
Para aqueles militantes trocados, as dúvidas e incertezas foram imensas, já que eles não estavam diretamente envolvidos nas negociações, não tinham informações, não conheciam os demais companheiros que seriam libertados, desconfiando muitas vezes que podiam ser infiltrados da repressão, e ainda duvidavam da palavra diplomática dos repressores quanto à preservação de sua integridade física.

\section{Os sequestros no Brasil}

Dentro do quadro das ações bem-sucedidas foram quatro sequestros de diplomatas entre 1969 e 1970, que redundaram na libertação de 133 pessoas, conforme o quadro abaixo, que montamos a partir de informações dispersas. Foge às possibilidades desse artigo apontar onde estavam todas as pessoas que foram inseridas nas listas das ações, e por isso todos serão considerados "libertados" em troca dos respectivos sequestrados, considerando-se inclusive as crianças envolvidas. Há controvérsias pontuais, sobretudo no caso do embaixador suíço porque os sequestradores não tinham informações exatas, indicaram algumas pessoas que não estavam presas, e mesmo pessoas que não quiseram sair do país. Abaixo tentamos sintetizar os dados que se encontram espalhados em relatos e materiais dispersos sobre os sequestros.

Quadro 1: Sequestros de Diplomatas

\begin{tabular}{|c|c|c|c|c|c|}
\hline Início & Fim & DIPLOMATA & $\begin{array}{c}\text { SEQUESTRADORES/ } \\
\text { Organização }\end{array}$ & Resgatados & Destino \\
\hline $4 / 9 / 1969$ & $6 / 9 / 1969$ & \begin{tabular}{l}
\multicolumn{2}{l}{ Embaixador dos } \\
Estados Unidos \\
Charles Burke \\
Elbrick.
\end{tabular} & $\begin{array}{l}\text { DI/GB } \\
\text { MR8 / ALN }\end{array}$ & 15 & México \\
\hline $11 / 3 / 1970$ & $16 / 3 / 1970$ & $\begin{array}{l}\text { Consul do Japão, } \\
\text { Nobuo Okushi }\end{array}$ & VPR & $8^{15}$ & México \\
\hline $11 / 6 / 1970$ & $15 / 6 / 1970$ & $\begin{array}{ll}\text { Embaixador } & \text { da } \\
\text { República } & \\
\text { Federal } & \text { da } \\
\text { Alemanha, } & \\
\text { Ehrenfried } & \text { von } \\
\text { Holleben } & \\
\end{array}$ & ALN, VPR & 40 & Argélia \\
\hline 7/12/1970 & 15/1/1971 & $\begin{array}{l}\text { Embaixador da } \\
\text { Suíça, Giovani } \\
\text { Enrico Bucher }\end{array}$ & VPR & 70 & Chile \\
\hline
\end{tabular}

A data de início se refere ao sequestro de fato, não à organização e planejamento do mesmo. Organização da autoria a partir de dados dispersos em várias fontes.

15 No caso dos resgatados em troca da liberdade do cônsul japonês, três eram crianças, os filhos menores de "Damaris Lucena, mulher de Antônio Lucena, assassinado dias antes pela repressão, e seus três filhos menores". http://memorialdademocracia.com.br/card/consul-do-japao-e-trocado-por-presos 
Há outros casos de sequestros de características distintas. Em janeiro de 1970 ocorreu o sequestro do Voo 114 pela VAR-Palmares. Tomaram um avião que saiu de Montevidéu ao Rio de Janeiro. Embora tenha sido realizado fora do Brasil, o foi por militantes brasileiros no contexto da ditadura brasileira. O desvio dos sequestradores levou o avião para Cuba, o que foi alcançado após 47 horas de tensão na tripulação e passageiros. Este sequestro foi comentado na documentação diplomática chilena, já que parte dos passageiros que estavam no avião eram chilenos, e havia no avião documentação diplomática do Chile. O documento não deixa de reclamar do tratamento que fora dado aos passageiros que foram usados como reféns quando foram recebidos em Cuba: "não foi permitido a eles abandonar o hotel, e dentro dele apenas podiam andar acompanhados de policiais armados". ${ }^{16}$

Entretanto, os grupos que promoviam os sequestros nem sempre tinham o preparo necessário para lidar com as situações inesperadas que apareciam, como foi o caso do sequestro do cônsul norte-americano ocorrido em Porto Alegre. Segundo relatos na imprensa local, a ação de sequestro não se completou e "em menos de 24 horas" praticamente todos haviam sido capturados. O sequestro é tido como fato gerador de uma "reorganização do aparato repressivo" no Rio Grande do Sul. ${ }^{17}$ Com isso, outras tentativas não foram sequer levadas adiante porque os riscos eram bastante altos, e era um tipo de ação que necessitava muito preparo.

Ocorreu ainda o sequestro da aeronave Caravelle da Cruzeiro do Sul, em 1/7/197018, no Rio de Janeiro. Dele participaram Fernando Palha Freire, Colombo Vieira de Sousa Jr, Jessie Jane e Eiraldo Palha Freire (assassinado na ação). A repressão foi feroz ainda na pista de decolagem, estourando os pneus do avião "com metralhadoras e iniciaram uma complicada operação cobrindo totalmente o Caravelle com uma espuma pegajosa que impedia a visão para fora da nave, enquanto que pelos tubos de refrigeração introduziram mangueiras que injetaram gás lacrimogênio" ${ }^{19}$ No processo posterior de apuração de dados a repressão tentou responsabilizar os demais militantes pela morte do companheiro: "Os três presos sobreviventes da tentativa de sequestro do avião foram acusados pela morte de Eiraldo e no decorrer do julgamento, a Promotoria concordou com a versão da defesa de que Eiraldo havia cometido suicídio" ${ }^{20}$ Esse caso mostra que a repressão empreenderia também posteriores batalhas jurídicas. A relatora da Comissão de Familiares de Mortos e Desaparecidos Políticos, Suzana Lisboa indicou que "ora Eiraldo fora morto por Colombo, ora suicidara-se, tendo morte imediata no avião, ora fora socorrido, morrendo posteriormente" 21 . Esse tipo de confusão presente na documentação mostra a dificuldades que os próprios repressores tinham de acertar uma versão oficial para os casos, o que era somado à censura à imprensa e ao silêncio imposto.

\footnotetext{
16 Regreso de avión de VARIG secuestrado a Cuba. De: Direccion de Relaciones Internacionales / Embajada de Chile, n. 1062, Confidencial RIA, 2989/15, 19/3/1970. Para: Ministério das Relações Exteriores, Santiago.

17 Sulena Cerbaro e Alessandra Gasparotto, O RS no contexto da Ditadura militar: o caso do "sequestro" do cônsul norte-americano. Anais do II Encontro de Pesquisas Históricas. PPGH/PUCRS, Porto Alegre, 2016, p. 79. 18 Temos registro de uma outra tentativa de sequestro realizado em 22/2/1975, que foi debelado pelos agentes de segurança (Jornal do Brasil, 23/2/1975, capa).

${ }_{19}$ Confidencial RIA, n. 911/52, Rio de Janeiro, 9/7/1970, 378 De Embajada de Chile para: Ministério das Relações Exteriores, Santiago.

20 Almeida et all, op. cit,, p. 200

21 Idem.
} 
Em 1970 houve um longo e exaustivo sequestro realizado no Uruguai pelo grupo Tupamaros contra o cônsul brasileiro, Aloysio Dias Gomide. O governo uruguaio não aceitou a negociação por um diplomata, mas o caso se resolveria com pagamento de grande cifra de dinheiro. A diplomacia chilena comentou que se "evidenciou um unânime sentimento de mal-estar e preocupação nos meios oficiais e na opinião nacional, que responsabilizou o governo uruguaio por sua "intransigência" e exigiu do Itamaraty a maior pressão para obter a liberdade do representante consular" ${ }^{22}$ Essa postura uruguaia pode ter interferido para o fim das possibilidades de sequestros brasileiros, já que não aceitava a negociação nos termos propostos.

\section{Uma visão geral dos sequestros de diplomatas no Brasil}

O primeiro sequestro ocorreu em 4/9/1969, organizado pelo MR8, libertou quinze presos que foram levados para o México em troca da vida do embaixador norte-americano Charles Burke Elbrick. Segundo o historiador e ex-militante Jacob Gorender, essa foi “a primeira operação do gênero no mundo, na história da guerrilha urbana" ${ }^{23}$. Este caso teve um adicional ideológico que era o fato de ser o sequestro do embaixador "do império", contra o qual toda a esquerda combatia. Estes fatos ficaram bastante conhecidos pelo livro de um dos participantes do sequestro, O que é isso companheiro, de Fernando Gabeira. ${ }^{24}$ Também é abordado com detalhes na obra de Mario Magalhães que mostra que Carlos Marighella, o líder da ALN, não estava a par desse grande feito de sua organização quando ela foi desfraldada. ${ }^{25} \mathrm{O}$ autor traz a assustadora cifra da repressão ocorrida durante o sequestro. Se a repressão não podia atuar diretamente no local do sequestro, sob pena de causar a morte do embaixador, fora dali ela era segura, constituindo um "furor repressivo que somaria 1800 detenções nas 78 horas do cativeiro do embaixador" ${ }^{26}$

A obra de Silvio Da-Rin que entrevistou militantes sobreviventes do sequestro traz importantes questionamentos sobre esse caso. $\mathrm{O}$ autor, militante à época, propõe que esse sequestro demarcou uma mudança de padrão da repressão no Brasil, indicando que "sem dúvida, os organismos de segurança passaram a atuar de forma cada vez mais coordenada" 27 mas, lembra ele, a Operação Bandeirantes - OBAN já havia sido criada, “dois meses antes do sequestro", e portanto já indicava um aprofundamento dos métodos de repressão e tortura. Segundo ele,

A decisão de dar combate inclemente aos grupos de esquerda havia sido tomada em 1968, nos bastidores da decretação do AI-5. No primeiro trimestre de 1969, tanto a VPR quanto o Colina tiveram dezenas de militantes presos. No segundo, a dissidência de Niterói foi praticamente

\footnotetext{
22 De Embaixada do Chile, 2900, Confidencial RIA 1112/67, RJ, 24/8/1970. Reacciones brasileiras ante sucesos Montevideo.

23 Jacob Gorender, Op. Cit., p. 184.

24 Fernando Gabeira, O que é isso companheiro? São Paulo, Codecri, 1980

${ }^{25}$ Mario Magalhães, Marighella: o guerrilheiro que incendiou o mundo. São Paulo, Companhia das Letras, 2012,

p. 488 e segs.

26 Idem, p. 495.

27 Silvo Da-Rin, Hércules 56: o sequestro do embaixador americano em 1969, Rio de Janeiro, Zahar, 2007, p. 20.
} 
exterminada. No terceiro, foi a vez de a Ala Vermelha sofrer diversas quedas, poucos dias antes do rapto do embaixador ${ }^{28}$.

Um dos sequestradores descreveu posteriormente em suas memórias

Na mesma noite, a ditadura anunciou que 'por razões humanitárias', aceitava as exigências. Para dar cobertura legal à saída dos presos, editou o Ato Institucional no 13, criando a pena de banimento perpétuo do país, à qual seriam 'condenados' os presos libertados 29 .

Ou seja, estavam livres, mas não existiam mais enquanto cidadãos brasileiros. $\mathrm{Na}$ medida em que as prisões iam acontecendo o medo de que os companheiros não resistissem à tortura e acabassem revelando informações era enorme. A regra combinada estabelecia 24 horas de silêncio em caso de prisão, mas nem todos conseguiram cumprir esse combinado. E não foram poucos os casos em que as informações erradas passadas aos repressores acabaram levando involuntariamente à prisão de novos companheiros. Esse clima nos ajuda a entender e dimensionar o alcance da necessidade dos sequestros como uma ação defensiva que visava proteger militantes e leva-los para um local em que estivessem seguros.

O segundo sequestro foi o do cônsul japonês, Nobuo Okuchi, ocorrido em São Paulo em 11/3/1970, levando à troca de cinco presos políticos. O sequestro foi realizado dia 11 e no dia 16 os libertados já chegaram ao México. Tratou-se de um processo distinto:

O cenário do sequestro do cônsul-geral do Japão é completamente diferente do cenário existente durante o sequestro do embaixador Elbrick. Em primeiro lugar, o local não foi o Rio de Janeiro, mas sim São Paulo. Em segundo, o governo já não era mais provisório, mas sim o governo do $3^{\circ}$ presidente do regime, com nova composição de ministros e demais cargos políticos. Em terceiro e último lugar, há o sequestro não de um embaixador, mas sim de um cônsul. ${ }^{30}$

Do ponto de vista prático foi resolvido rapidamente, embora tenha tido o menor número de trocas, sendo um ato desesperado de salvar informações. Deste sequestro participaram 15 militantes dos quais oito foram presos e cinco morreram nas mãos da repressão. Foi uma ação com altos riscos. Um militante da VPR que tinha importantes informações sobre Carlos Lamarca e seu esquema de treinamento de guerrilha no Vale da Ribeira levou a que o processo fosse rápido e direto através da ação, comandada por Ladislau Dowbor e Eduardo Leite. O alvo desse sequestro era a libertação de Mario Japa, que conhecia o local da área de treinamento. Sua prisão levou à parcial desmobilização da área de treinamento, inclusive com a ida de Lamarca à zona urbana para realização da ação. $\mathrm{Na}$ lembrança registrada por Liszt Vieira, um dos sequestradores, houve impasse sobre quantos seriam os presos pedidos em troca pelo cônsul. Tinham pressa, mas pedir apenas o

28 Idem.

${ }^{29}$ Cid Benjamin, Gracias a la vida: memórias de um militante. Rio de Janeiro, José Olympio, 2013, p. 113.

30 Juliana Ramos Luiz. A ditadura civil-militar diante da crise: os sequestros de diplomatas no Brasil e a análise do processo decisório em política externa. NEIBA, volume IV, n.1, agosto 2015, p. 38. 
alvo poderia enfraquecer a negociação. Foi um "sequestro encomendado, para soltar rapidamente alguém que não pode continuar preso, porque sua prisão compromete a segurança de toda a organização", segundo o líder da VAR-Palmares, Antonio Espinosa. Ao fim decidiram por cinco pessoas, sendo uma delas uma religiosa, forma de sensibilizar a opinião pública, embora após libertada ela tenha se recusado a falar sobre o ato. Segundo seu relato

Num domingo ensolarado, saímos com o cônsul da casa onde passamos quatro dias conversando sobre amenidades. Ele lutou na segunda guerra mundial na Marinha japonesa. Tinha histórias para contar. Entendia até de balé clássico japonês. Apesar do clima tenso, a relação com ele foi gentil e amigável. Falávamos em inglês e ele acompanhou todo o processo de negociação. Até deu palpite nas mensagens que enviávamos à polícia. ${ }^{31}$

O objetivo imediato foi alcançado. Diógenes Oliveira, um dos libertados no sequestro mostra o clima tenso: "nós não sabíamos de ríamos ou chorávamos, com medo de que nos matassem" 32 .

O nome de Toledo foi colocado na lista, e as autoridades mandaram dizer que não havia nenhum Toledo preso. A VPR não conhecia o seu verdadeiro nome: Joaquim Câmara Ferreira. Toledo era um codinome. Mas já haviam matado o Toledo, o segundo homem da ALN. Foi então que Lamarca mandou colocar o meu nome no lugar dele. 33

Relata ainda o adicional preconceito racial ao qual foi submetido Otávio Angelo, da ALN, libertado junto: "cobriam-no de insultos. 'Negro fedido, nós aqui na merda, combatendo terrorista e você vai assistir a Copa no México'. E davam porrada nele. 'Tu vais chegar no México, mas não vai ser assim, pois nós vamos te matar antes"34, diziam. Assim, mesmo que o governo e os repressores estivessem diplomaticamente obrigados a realizar a libertação, não era sem terror que obedeciam a ordem. No caso desse sequestro como no caso do embaixador norte-americano, os militares ainda constrangeram os libertados com algemas até a chegada no território mexicano. Apenas com a intervenção dos policiais locais é que retiraram as algemas dos brasileiros, dentro da lógica da "guerra revolucionária", como indica também Da-Rim:

Certamente, a derrota sofrida com a libertação de 15 presos políticos, a divulgação pública do manifesto e a humilhação internacional que isso representou para a ditadura foram usadas como justificativa para a supressão das garantias individuais e o recrudescimento do regime de força. O saldo da onda repressiva que se seguiu imediatamente ao sequestro é eloquente: quase a metade dos participantes da ação caiu antes que a captura de Elbrick tivesse completado um mês. Em janeiro de 1970, ano em que mais três sequestros resultaram na libertação de outros 115

\footnotetext{
31 Liszt Vieira, A busca: memórias da resistência. São Paulo, Hucitec, 2008, p. 20.

32 Hatsuo Fukuda, Diógenes o guerrilheiro. Ousar lutar, ousar vencer! Porto Alegre, Evangraf, 2014

33 Idem.

34 Idem, p. 110.
} 
presos políticos, a repressão atingiu um novo patamar de organização e planejamento, com a criação dos DOI-CODIS. ${ }^{35}$

Após esse sequestro a ira da repressão seria implacável contra um dos sequestrados, Eduardo Leite. Preso, sequestrado pela repressão do DOPS, passou mais 42 dias de sevícias e finalmente foi assassinado de acordo com o relato de Suzana Lisboa:

A notícia oficial da morte de Eduardo teve o objetivo de evitar a inclusão de seu nome na lista das pessoas a serem soltas em troca da vida do embaixador da Suíça no Brasil (...) Seu nome encabeçava a lista e seria constrangedor soltá-lo, pois, oficialmente, estava foragido e, além do mais, completamente desfigurado e mutilado pela tortura a alternativa foi forjar mais uma morte em tiroteio. ${ }^{36}$

Enquanto ocorria o sequestro do embaixador suíço, Bacuri foi morto em situação de bárbara tortura na prisão, como forma de evitar que seu nome fosse colocado na lista de presos a serem trocados: "foi executado com quatro tiros, um deles no olho direito. Seu corpo foi desovado em um cemitério. Continha escoriações, hematomas e queimaduras" 37. As marcas do Terrorismo de Estado ficam visíveis na forma como a repressão atuava: terror, desrespeito a leis internacionais, tortura, violência, criação de versões. 38 Ou seja, embora no âmbito público houvesse a resolução dos casos de sequestro, internamente os participantes das ações foram massacrados sempre que a repressão conseguiu alcança-los.

O terceiro sequestro foi o do embaixador da República Federal da Alemanha, Ehrenfried von Holleben, realizado pela ALN e VPR no dia 11/6/1970. Através dele 40 presos foram libertados e entregues na Argélia. Logo na sequência do sequestro os nomes dos resgatados são banidos do território brasileiro, assim como já ocorrera nos anteriores. ${ }^{39}$ Se voltassem ao Brasil corriam risco de vida pois seriam especialmente visadas pelos agentes da repressão. O desfecho foi realizado na Argélia, e os militantes não perderam a oportunidade de denunciar as torturas sofridas no Brasil:

O representante da embaixada brasileira na Argélia entrou em contato com o Ministério das Relações Exteriores no Brasil por telefone, e o Ministério fez o comunicado oficial para que o embaixador fosse solto. O embaixador alemão foi solto no dia 16 de junho, no dia seguinte ao desembarque dos brasileiros em Argel. Todo o caso foi amplamente divulgado pelos jornais brasileiros, os quais descreviam os banidos como 'terroristas'. Na imprensa

\footnotetext{
35 Da-Rin, op cit, p. 20.

36 Almeida, et al, Op Cit, p. 214.

37 Ayrton Centeno, Os vencedores: a volta por cima da geração esmagada pela ditadura de 1964, São Paulo, Geração, 2014, p. 443.

38 Enrique Padrós, Terrorismo de Estado: reflexões a partir das experiências das Ditaduras de Segurança Nacional. In: GALLO, C. A e RUBERT, S. (orgs). Entre a memória e o esquecimento: estudos sobre os 50 anos do Golpe civil-militar. Porto Alegre, Deriva, 2014.

39 Elementos banidos do território nacional. Informação n. 265.004. CISA/RJ, 29/6/1970. Todos os documentos citados provenientes do Ministério das Relações exteriores do Chile foram por mim traduzidos livremente.
} 
argelina, foram transcritas declarações prestadas pelos exilados, nas quais havia denúncias de tortura nas prisões. ${ }^{40}$

Na documentação da Embaixada consta que nesse caso a censura imposta à imprensa foi ferrenha, e ainda assim especularam sobre possibilidade de que a troca se desse com o Chile, ao que o embaixador esclarecia:

Jornais de escassa circulação me atribuem declarações absolutamente falsas no sentido de que haveriam oferecido mediação e recepção no Chile dos presos que seriam trocados pelo Embaixador da Alemanha. Me absterei por hora, de desmentir as notícias pois poderiam prejudicar as negociações que devem ser realizadas nas próximas horas entre Governo e raptores. ${ }^{41}$

O Ministério já havia sido alertado sobre os acontecimentos, sabendo que o sequestro foi planejado pela ALN e VPR. ${ }^{42}$ Em documento do dia 14 o Embaixador informa que nome do Chile consta como possível local de destino: "governo do Brasil deve obter asilo para eles na Argélia, México ou Chile, nessa ordem de preferência, fixando em 36 horas o prazo para seu embarque" 43 . Já no dia seguinte divulga a notícia de que a Argélia aceitou receber os libertados. ${ }^{44} \mathrm{O}$ contexto internacional acabou pesando para a rápida resolução desse caso:

O clima envolvendo o caso dos sequestros passou a compor definitivamente o cenário nacional. Os demais sequestros que ocorriam na América Latina, atrelado aos sequestros já ocorridos no pais, demonstravam a força que esta tática de luta tinha alcançado. O clima nacional ainda estava aflorado já que, pouco antes do sequestro do embaixador alemão, houve a tentativa de sequestro do cônsul-geral norte americano Curtis Cutter em Porto Alegre, sem sucesso, e o trágico caso do embaixador alemão sequestrado na Guatemala, assassinado após a negativa do governo guatemalteco em aceitar as condições impostas pelos sequestradores. ${ }^{45}$

Em 4 de abril de 1970 havia ocorrido a tentativa frustrada de sequestro do cônsul norte-americano em Porto Alegre. E em um sequestro na Guatemala ocorrera a morte do sequestrado, o que colocou o governo brasileiro em situação muito delicada, pois não queria que o mesmo ocorresse no Brasil. Ademais, o embaixador Charles Elbrick, que teve sua vida assegurada no primeiro sequestro, criou uma situação inusitada para o governo brasileiro, criticando a falta de segurança do pessoal diplomático. O relato da Embaixada do Chile esclarece que:

\footnotetext{
40 Fabio Lucas Cruz, Brasileiros no exílio: Argel como local estratégico para a militância política (1065-1979). Tese de Doutorado em História, USP, 2016, p. 88.

${ }^{41}$ De Embachile Rio. Remigrama 63, n. 64, 13/6/1970.

42 De Embachile Rio. Informe 63, 12/6/1970.

43 De Embachile Rio, n. 67, 14/6/1970.

44 De Embachile, Rio, GM 68, Resutelex GM 47, 15/6/1970.

${ }^{45}$ Luiz, op. Cit, p. 39.
} 
Em nota divulgada hoje, o Itamarati expressa 'que considera desnecessária essa manifestação pública quanto a Embaixada dos Estados Unidos que não ignorava o cuidado com que as autoridades brasileiras asseguraram proteção dos representantes estadunidenses e dos demais países'. Agrega comunicado que o Cônsul norte-americano havia recusado proteção oficial oferecida. ${ }^{46}$

O fato é que Elbrick seria afastado da embaixada ${ }^{47}$. E o governo brasileiro esforçouse para explicitar uma posição: "não economizará esforços para determinar paradeiros do Embaixador e garantir sua integridade física". O informe indicava ainda que "o sequestro foi unanimemente repudiado pela imprensa, círculos oficiais políticos privados, eclesiásticos e opinião pública em geral"48. O contexto foi favorável ao desfecho do sequestro, o que se dava em momento desesperador, pois a repressão estava ferrenha, desbaratando organizações inteiras como seria o caso da VAR-Palmares.

Embora o sequestro passasse a impressão de que a guerrilha urbana seguia forte, a situação das organizações da luta armada era dramática. A VPR, idealizadora do plano, tinha tão poucos militantes que para realizar a ação teve de pedir ajuda à ALN, que colaborou com dinheiro, armas e quadros. A situação da VPR era tão precária que, confirmada a chegada dos companheiros a Argel, não havia carro para conduzir o embaixador ao local onde ele seria libertado. A Kombi reservada para a missão tinha sido rebocada por estacionamento em local proibido. A libertação teve de esperar 24 horas, à espera de um fusca. Ao se despedir dos sequestradores, Von Holleben afirmou: "Pensei que vocês fossem mais organizados". ${ }^{49}$

O tema dos sequestros estava na pauta das organizações internacionais. A Organização dos Estados Americanos teria indicado que "expressou que apresentará projeto de resolução propondo medidas efetivas para caracterização, prevenção e sanção de crimes de terrorismo e sequestro". ${ }^{50}$

Uma forte prova de que os sequestros levaram à reorganização da repressão está no documento enviado pelo Departamento de Segurança Interna do Ministério de Relações Exteriores brasileiro. Ele chega a reclamar da falta de colaboração de polícias fora do país, deixando claro que o governo brasileiro estava investindo em buscar os sequestradores onde quer que eles estivessem, e o documento é de 1974:

A DSI/MRE estando empenhada em identificar e localizar a presença no exterior, em determinados países, de terroristas brasileiros foragidos, considerou a possibilidade de que certos grupos operativos, ligados por laços ideológicos, de amizade pessoal ou de convivência, se tenham

\footnotetext{
46 De Embachile Rio, RIA 44, 9/4/1970.

47 De Embachile DG 46 Resucircular, 12/4/1970 informava que todas as embaixadas tiveram sua segurança reforçada. Sobre a renúncia de Elbrick: Aerograma Confidencial Ria n. 114, 13/8/1970.

48 De Embachile, Rio, n. 64, 13/6/1970.

49 http:/ / memorialdademocracia.com.br/card/40-sao-trocados-por-embaixador-alemao

50 De Embachile, 7160, 80, 20/6/1970, Correa.
} 
rearticulado ou procurou conservar as antigas ligações entre seus membros, fora do Brasil.

2. Nessas condições, ao ser verificada a presença de algum desses terroristas em determinado país, desde que se saiba quais foram seus outros companheiros de ação no Brasil, torna-se mais fácil, como ponto de partida, procurar localizar os demais membros do grupo ou célula.

3. Embora a colaboração das autoridades locais em muitos países deixe a desejar, sempre resta, em outros, a possibilidade de, em sendo procurados nominalmente, se detectar a presença desses terroristas. ${ }^{51}$

Portanto, mesmo banidos do território nacional, os envolvidos nos sequestros seriam acompanhados de perto pelos agentes da repressão brasileira, exigindo a colaboração internacional que seria posteriormente corporificada no Plano Condor.

\section{O caso do embaixador suíço}

O sequestro do embaixador, Giovanni Enrico Bucher, foi organizado pela Vanguarda Popular Revolucionária - VPR, e ocorreu no dia 7/12/1970, no Rio de Janeiro, só tendo desfecho 40 dias depois, em 13/1/1971, quando o embaixador foi libertado com vida e saúde. Esse caso gerou reações contra o Brasil, em decorrência das denúncias de tortura generalizadas após o desfecho. O documentário Brazil, a report on torture, de e Haskell Wexler e Saul Landau, filmou logo da sua chegada no Chile, os depoimentos de alguns dos libertados no sequestro, que discorreram em detalhes sobre as formas da tortura que haviam sofrido no Brasil. Foi o caso com maior duração, o que nos mostra que as dificuldades nas negociações aumentavam e corria o risco também de ter maior impacto político.

Foram 40 dias de cativeiro, 70 presos trocados, e o fim dos sequestros dali pra frente. A ditadura brasileira já tinha preocupações com as fronteiras e demais países do Conesul, há documentos que insistem na necessidade de organização de cooperação entre os países pela repressão. O Brasil cobrava que estava preocupado com "atividades terroristas", que "os contatos e comunicações entre guerrilheiros e sequestradores pareciam mais fáceis", 52 emitindo uma preocupação que mais tarde seria enredada no Plano Condor. Em 7/12/1970 a notícia trazida pelo aerograma era simples: “embaixador suíço Bucher foi sequestrado hoje. Policial que o custodiava foi gravemente ferido. Até o momento investigações negativas sequestradores não se comunicaram com autoridades. Embaixador estaria ileso"

53. Dois dias depois, um novo aerograma dizia que "até o momento carece-se de notícias sobre o paradeiro do Embaixador suíço. Autoridades dizem que mensagens presumidamente de origem dos sequestradores são falsas. Não deve-se descartar a possibilidade de que sejam autênticos e que o Governo esteja considerando condições dos

\footnotetext{
51 Ministério das Relações Exteriores do Brasil. Pedido de Busca. Confidencial. 22/1/1974. Arquivo Nacional, Brasília.

52 Aerograma De Embachile Rio, 14/12/1970. O problema se estenderia além Atlântico, englobando Paraguai e Chile.

53 Aerograma de: Embachile Rio RIA 194, 7/12/1070, n. 15184. Correa.
} 
sequestradores" 54 . Ou seja, a embaixada não sabia quais eram as condições da conversa entre sequestradores e governo, nem que estaria envolvida no processo de negociação.

É em um documento de 10/12/1970 que o Jornal do Brasil que a notícia aparece na Embaixada. Segundo o aerograma, o JB “disse hoje que 'um funcionário diplomático admitiu ontem sua preocupação frente notícias que incluem Chile entre Países escolhidos para receber presos trocados pelo Embaixador Suíço". Ainda segundo a mesma fonte, "o mesmo diplomático haveria dito que isso poderia dar argumentos a radicais brasileiros que defendem linha dura contra governo Allende" ${ }^{55}$ Começam as negociações e junto com elas as dúvidas sobre a escolha de um país socialista para os "radicais" brasileiros.

O governo brasileiro aguardava que fosse entregue uma carta de próprio punho do embaixador suíço para confirmar seu estado de saúde. O documento chileno considera "surpreso anúncio, depois de prolongado silêncio oficial parecem confirmar conjeturas do meu Telex RIA 196 de ontem". Apresenta a possibilidade de que "os setenta prisioneiros iriam em dois grupos de dois cada um a Argélia respectivamente e outro de vinte ao México", dando a entender que a Polícia Federal já estaria tomando providências nesse sentido. Como o cenário era de dúvidas, o Ministério já pedia orientações:

o subscrito não recebeu nenhuma petição ou insinuação sobre possível asilo territorial no Chile do grupo de presos assinalados (dada sua urgência) no assunto, agradecerei instruções imediatas para estar em condições de dar uma pronta resposta se essa Embaixada receber solicitação oficial. ${ }^{56}$

A embaixada teria recebido informações através do jornal El Mercurio sobre a intenção de que o país recebesse aqueles que seriam trocados pelo Embaixador, segundo a qual "as mesmas fontes indicaram que a escolha deste país da América Latina concitou forte oposição entre as forças armadas brasileiras" 57 . O informe diz também que isto estaria levando ao atraso das negociações, pois "para os referidos militares, a opção por este país latino-americano, um dos mais imediatos vizinhos do Brasil, é uma provocação inadmissível", e isso seria o mesmo que aceitar "no próprio continente um núcleo ativo de oposição". A distância de $2.300 \mathrm{~km}$ entre a fronteira brasileira e a capital chilena era apontada como fator de preocupação. Assim se conclui o aerograma: "De fontes bem informadas transcendeu que o Governo estaria disposto a liberar os 70 presos em que pese o elevado da cifra exigida desta vez, mas que nunca aceitará que sejam levados ao Chile". Diante disso, a embaixada pede orientações de como proceder.

O Ministério produz então um extenso documento com orientações para o caso de que a Embaixada venha a ser procurada. Inicialmente, o documento do Ministério esclarece que “a) por óbvias razões Governo do Chile não pode negar sua colaboração para solucionar um problema extremamente delicado e grave". Mas, emenda que, é preciso ter cuidados devido ao uso político que poderia ser feito contra o Chile.

\footnotetext{
54 Aerograma de Embachile Rio. 196, Cifrado, 9/12/1970, 15572,

55 Aerograma de Embachile Rio. GS 198, 10/12/1970, Correa.

56 Aerograma de Embachile Rio. GS 197. 10/12/1970, Correa.

57 Santiago, 10/12/1970. Embachile, Rio. Minrelaciones. Telex 148/79684. Cifrado.
} 
b) Governo do Chile que pratica cuidadosa e lealmente princípio de não intervenção compreende que sua atitude nesses assuntos pode e deve ser objeto de exploração política por elementos interessados em desfigurar a imagem externa do novo Governo Popular; não obstante, tanto em respeito a nossa tradição como por princípios humanitários que nos inspiram, nós assinalamos claramente o caminho da cooperação e de abrir portas do Chile àqueles que serão postos em liberdade..$^{58}$

Este documento propõe ao embaixador uma condição fora do âmbito do sequestro, que se permitisse acrescentar a permissão do ingresso no Chile de outros sete asilados que se encontravam no Rio de Janeiro e em Brasília, "para o qual esse Governo deveria oferecernos ao mesmo tempo os respectivos salvo-condutos". O embaixador chileno no Brasil responde que:

Esta condição aparece desproporcional frente a um fato que causou profunda repercussão internacional e externa, em que está em perigo a vida do Embaixador suíço e poderia deixar nosso país em posição humilhante. Em caso de qualquer eventual petição do Governo Brasileiro para admitir presos políticos em nosso território, peço autorização para eliminar dita condição $(. . .)^{59}$

Outro item que causaria estranheza no Embaixador Chileno do Brasil se trata de mais uma sugestão feita pelo Ministro no sentido de permitir uma re-expatriação dos asilados, com os custos a serem assumidos pelo governo brasileiro. Assim está elaborado o item:

e) desejosos de reincorporar à vida normal os presos políticos compreendemos que alguns deles, quiçá grande parte, desejará estar no Chile apenas tempo limitado para continuar rumo a outros países, Argélia, Cuba ou outro. No qual poderiam alcançar maiores oportunidades de encontrar trabalho ou outra atividade remunerativa. Daí que o Governo do Chile desejaria que o do Brasil não apenas assegurasse o traslado a seu custo ao Chile de todos os que devam vir aqui, mas que expressasse verbalmente ou por escrito, que adotaria as medidas necessárias para assegurar a reexpedição a outros lugares das pessoas que o indicassem no Chile ou no Rio mesmo. ${ }^{60}$

Para quem conhecia minimamente as rotas dos militantes brasileiros no exterior saberia que é absurda a sugestão de que o Brasil facilitasse a ida de qualquer um deles para Cuba. Neste país eles facilmente receberiam treinamento de luta armada. Aqueles que por vias próprias conseguiam chegar a Cuba o faziam por meio de complicadas conexões aéreas internacionais para poder apagar suas pistas para a repressão. Neste ponto também o embaixador sugere uma modificação, explicitando que "O Brasil, nos casos anteriores transportou a seu custo os presos políticos resgatados ao México e Argélia". Desta forma,

58 Telex RIA 149, Santiago, 10/12/1970. Circulação restrita.

59 Resutelex149. Embachile Rio GM-GS-RIA 201, cifrado, 15/12/1970. Correa. O documento aponta outra forma de resolver o problema dos 7 asilados.

60 Telex RIA 149.P. 2. 
completa: "estimo improvável aceite tomar a seu cargo reexpedição posterior a terceiros países os presos liberados. Me parece que bastaria assegura-lhes que Chile favoreceria saída de seu território aos que voluntariamente quisessem abandoná-los, sem contribuição pecuniária brasileira". ${ }^{61}$ Essa discussão na verdade passa ao largo do fato de que os resgatados seriam banidos do Brasil, ou seja, deixariam de ter qualquer direito cidadão por parte do governo brasileiro, como já explicitamos. O documento do Ministério chileno dava ainda mais orientações no sentido de como esses itens deveriam aparecer, "deveriam aparecer como oferecidas espontaneamente pelo governo do Brasil", tocando ainda em ponto político bastante controverso:

Para conseguir que o Brasil compreenda a procedência e fundamento deste ponto de vista, deveria você argumentar, com reiterada e firme cordialidade, que desta maneira se iniciaria a missão de nosso novo Embaixador sem obstáculos, que ao ir-se a outros continentes uma boa parte destas pessoas sairiam da América do Sul e que estes argumentos chilenos revelam uma vez mais o espírito objetivo e construtivo que anima a nosso Governo. Alguns informes de agências noticiosas publicados aqui assinalam que nas Forças Armadas brasileiras existiu forte oposição a admitir Chile como país de refúgio, o qual se fosse efetivo poderia também inclinar esse Governo a admitir sugestões que transmito a você. ${ }^{62}$

O Embaixador responde a esse item especial dizendo que essas instruções "causariam atrasos perigosos para a vida do embaixador suíço e poderia saber-se que o Chile está colocando condições que provavelmente não seriam exigidas nem por México nem por Argélia, como sucedeu nos casos de sequestros anteriores" 63 . Trata-se de qualquer forma de exigências bastante inadequadas para o complicado da situação que se colocava pela frente. O próprio embaixador lembra que para parte da imprensa há uma imagem do Governo do Chile como "desejoso de receber presos políticos por afinidades ideológicas ou subversivas", e que o problema seria resolvido no âmbito militar. O "Presidente Garrastazu não ocultou sua séria preocupação pelo problema da subversão no Brasil e a necessidade de atuar com grande energia", de acordo com conversa realizada em encontro diplomático. Ou seja, já era de conhecimento geral a posição do governo chileno e o governo brasileiro estaria aprimorando seus métodos de controle dos seus "subversivos" 64 .

Uma nova correspondência de 14/15 de dezembro informa que finalmente a embaixada foi contatada pelo ministro brasileiro, Gibson ${ }^{65}$. O telex indicava que ele "desejava saber se o governo do Chile poderia dar asilo territorial a presos políticos que seriam resgatados pelo Embaixador Suíço. Disse-me que os sequestradores haviam indicado o Chile, México e Argélia para tais efeitos, sem assinalar ordem de predileção", sendo

\footnotetext{
61 Resutelex 149.

62 Telex RIA, 149, p.2.

63 Resutelex 149.

64 A documentação do Centro de Inteligência do Exército-CIEX nos mostra que houve um sistemático acompanhamento de agentes brasileiros da ação dos brasileiros banidos em sua vida clandestina no Chile, ainda sob o governo da Unidade Popular.

65 Mario Gibson Barbosa era o Ministro das Relações Exteriores do Brasil durante o período do sequestro.
} 
possível dividir os destinos. Correa indica que respondeu de acordo com as instruções recebidas antes, pelas letras “ $a, b, c$ ”, destacando que:

Fiz presente a condição assinalada por você na letra " $\mathrm{e}$ " do mesmo telex e respectivo fundamento. Chanceler a rechaçou imediatamente, qualificando-a de humilhante. Posteriormente disse que ela era positiva, já que demonstrava o efetivo interesse do Chile de não se converter em uma central de subversão latino-americana. No entanto, expressou que sem necessidade de consultar essa condição com o Presidente, insistia em rechaça-la. ${ }^{66}$

O documento ainda indica que "audiência foi extremamente cordial e compreensiva das respectivas posições", e que a embaixada do México também foi chamada para idêntica petição, presumindo que a da Argélia também o fora. Instruções urgentes são solicitadas e a resposta insiste no assunto, buscando mais uma vez delimitar que o Chile estaria querendo livrar-se de qualquer implicação política:

Meu telex 149 não colocava condições para sua recepção. Apenas expressava desejos ou sugestões que estimamos positivas. Por conseguinte, não entendemos que Ministro Gibson tenha podido estimar condição humilhante à ideia exposta na letra " $\mathrm{e}$ " do telex. Com ela se pretendia que um maior número possível dos ditos presos pudessem viajar posteriormente para fora de área sulamericana, o que indubitavelmente resultaria de interesse do Brasil. ${ }^{67}$

Reitera ainda o interesse de repartir os resgatados entre os países, dizendo que ao Itamaraty "manifestou compreensão de que veríamos com agrado que presos se repartissem entre Chile, México e Argélia"68, o que não viria a acontecer. O documento nos lembra da censura vigente no Brasil "governo tem praticamente silenciada a imprensa, rádio e televisão a respeito do sequestro", e que não tem clareza de como vão as negociações, aventando que os sequestradores poderiam estar exigindo publicação de manifestos "ofensivos para autoridade, reajuste em massa de salários, etc", como parte das negociações, o que não é aceito pela Ditadura brasileira, retirando o a caráter de apoio popular do sequestro.

O Ministério pede autorização chilena para divulgar o aceite do recebimento dos presos, o que foi feito, "pedindo encarecidamente que redação do comunicado deixasse claramente estabelecido que a iniciativa era brasileira, com o que concordou plenamente" 69 . Com isso ficaria claro que não partia do Chile qualquer iniciativa de receber os presos em seu território. Apenas em 22/12 o governo brasileiro acenou com uma lista de possíveis resgatados, mas ainda estava em discussão com os sequestradores, pois colocou veto em alguns nomes apresentados. Ocorre inclusive a prisão de um jornalista francês, acusado pelo

66 Remitelex 201. ROG. 15488. De: Embachile Rio. Cifrado. 14/15/12/1970. Para Gabinete Ministro.

67 Telex 154. Resutelex 201 e 202. De Minrelaciones para Embachile, Rio. 1154/37460. [Data ilegível]

68 De Embachile Rio Telex 204. Resutelex 154. 16/12/1970, Correa

69 De Embachile Rio. Telex 206. 17/12/1970. 
governo brasileiro de estar divulgando dados sobre o sequestro, o que estava terminantemente proibido. O chefe da Agência da France Press: "foi detido e acusado de possuir a lista de presos"70. Foi preso incomunicável. ${ }^{71} \mathrm{O}$ informe diz que o "encarregado de Negócios da Suíça expressou profundo temor pela possibilidade de o embaixador Bucher seja assassinado, ainda que tenha expressado esperança". Claro, em meio a tudo isso, esse risco de fato existia. Quando o governo se recusou a aceitar nomes na negociação, a VPR, após dar ultimato ao governo teria realizado votação na qual votara pela execução do Embaixador. No relato de Alfredo Sirkis, "tinha uns vinte a favor da execução. Só eu o José Roberto Rezende, que não estava no aparelho, fomos contrários"72:

O terceiro e mais importante voto pró-negociação era o do comandante em chefe. Após ler, um por um, os votos por escrito, expôs sua posição: era contra a execução, mas queria construir uma maioria. Os demais mantiveram suas posições. No dia seguinte, Ines Etienne Romeu, dirigente da organização, chegou de São Paulo e também aderiu a Lamarca. Que recorreu ao poder de veto que lhe dava o estatuto da VPR e derrubou a decisão da maioria da assembleia. (APUD CENTENO, p. 442).

Na avaliação de Sirkis, que participou do sequestro, essa decisão impediria a luta armada de ter qualquer imagem positiva junto à opinião pública. Além disso, está claro que salvou a vida dos 70 militantes, além de não colocar a perder todo o esforço dispendido no sequestro. Os fatos seguiram difíceis, já que governo e sequestradores demoraram a chegar a acordo e as formas de comunicação entre eles eram precárias, levando a riscos grandes. Há nomes vetados, há pessoas que não querem sair do país e há até pessoas que estavam livres indicadas para a troca. Isso se explica facilmente pela falta de informações que os militantes na vida clandestina tinham com relação aos demais companheiros.

Assim como nos casos anteriores, a ditadura não perderia a oportunidade de fazer aplicar métodos do Terrorismo de Estado com os presos na medida em que estavam sendo levados para a troca. Assim relata Aluizio Palmar, um dos libertados:

Só fiquei sabendo que eu estava na lista e que iria ser trocado pelo embaixador quando os guardas me tiraram do castigo e me levaram para um outro isolamento no segundo andar. Durante os dias em que fiquei no isolamento da parte de cima tentei recuperar-se dos suplícios daqueles dias (...) Além das aflições noturnas ainda havia as ameaças feitas pelos guardas penitenciários de que nós, os que estávamos na lista para troca pelo embaixador, seríamos jogados de helicóptero em alto-mar. ${ }^{73}$

Ele relata ainda que os guardas tentaram dissuadi-lo de aceitar a troca: "disseram-se que se eu declarasse que queria ser trocado pelo embaixador estaria assinando minha

70 De Embachile Rio. RIA 214. Cifrado, 22/12/1970.

71 Outro documento indica que ele ficou preso 27 horas e recebeu ordem de deixar o país em 4 dias: "Itamaraty informou oficialmente que as atividades de Pelou eram contrárias à segurança nacional”, já que teria tido contatos com os sequestradores. ROG 17993 de Embachile Rio, 24/25/12/1970.

72 APUD CENTENO, p. 442.

73 Aluízio Palmar, Onde foi que vocês enterraram nossos mortos? Curitiba, Travessa Editores, 2006, p. 288. 
sentença de morte" ${ }^{74}$ Ao fim e ao cabo, 70 nomes são indicados e a opção pelo Chile como local de acolhimento prevalece. No dia 11/1/1971 é enviado um documento "estritamente confidencial" onde constam os nomes daquelas pessoas, tratados como "presos políticos" que seriam enviadas ao Chile. ${ }^{75}$ Não tivemos acesso a documentos dos outros países explicitando o motivo da sua recusa, mas ressalte-se que ambos já haviam recebido exilados brasileiros. O Chile possuía exilados, era um país muito procurado por brasileiros, sobretudo pelas possibilidades de trabalho e estudos que oferecia no tumultuado quadro da Ditadura brasileira.

O destino que cada um desses militantes teria posteriormente no Chile vai ser bastante diversificado, mas uma boa parte deles acabaria tendo que deixar o país quando do Golpe de Pinochet em 1973, recomeçando novas jornadas de militantes que estavam impedidos de voltar para seu país. Um estudo pormenorizado sobre o destino das pessoas libertadas e mesmo dos sequestradores seria elucidativo das dificuldades encontradas nos sequestros, mas também das vidas que foram salvas a partir deles. No caso dos sequestradores, Carlos Lamarca, por exemplo, seria assassinado no sertão baiano, ainda em $1971^{76}$.

Alguns militantes acabaram entrando em profundo processo de depressão que os levaria ao suicídio. Muitas vezes a culpa por ter sido salvo e a lembrança dos companheiros que ficaram pelo caminho acabava sendo um fardo pesado demais. Trata-se de "suicídio como sequela da tortura", conforme tipificou a Comissão Nacional da Verdade:

As consequências da tortura, física ou psicológica, não se restringem ao momento de sua prática e tendem a atingir a personalidade da vítima de forma perene e levá-la a situações de extremo sofrimento e desamparo - e, em alguns casos, ao suicídio. (...) Esse foi o caso, por exemplo, de frei Tito de Alencar Lima, Gustavo Buarque Schiller e Maria Auxiliadora Lara Barcelos, banidos para o Chile em janeiro de 1971, em troca do embaixador suíço Giovanni Enrico Bucher. Depois do golpe militar que derrubou o governo de Salvador Allende, em setembro de 1973, os três tiveram que procurar asilo em outros países. ${ }^{77}$

Frei Tito, por exemplo, tentou suicídio logo após as torturas, mas não obteve êxito. O relatório conclui que "Banido do país, passou pelo exílio no Chile, na Itália e na França, onde se instalou em uma comunidade dominicana. Apesar de ter buscado tratamento psiquiátrico, frei Tito suicidou-se quatro anos mais tarde, no dia 7 de agosto de 1974, aos 28 anos". O caso não é muito distinto do de Maria Auxiliadora Lara Barcelos, militante da VAR-Palmares, que foi presa no Rio de Janeiro em novembro de 1969: “Dorinha viveu no Chile, México, Bélgica, França e, finalmente, Alemanha. Apesar de tentativas de tratamento e internações, não conseguiu se recuperar dos traumas produzidos pela tortura. Em $1^{\circ}$ de

\footnotetext{
74 Idem.

75 De Embaixada Chile, RJ, 11/1/1971. Lista de presos canjeados por Embajador Bucher. RIA 44/2. Estritamente confidencial.

76 Lamarca seria julgado e condenado pela morte durante o sequestro. Ver: Wilma Antunes Maciel. O capitão Lamarca e a VPR: repressão judicial no Brasil, SP, Alameda, 2006

77 Relatório da Comissão Nacional da Verdade, volume 1, 2014, p. 485
} 
junho de 1976, aos 31 anos, atirou-se sob um trem, em Berlim". O relatório da CNV traz ainda outros seis casos de pessoas que de fato ${ }^{78}$ cometeram suicídio em decorrência das sequelas das torturas e sevícias sofridas.

\section{As denúncias de torturas}

Um problema internacional para a ditadura brasileira apareceu depois da chegada dos brasileiros ao Chile. O documentarista estadunidense Haskell Wexler produziu o filme Brazil: A Report on Torture a partir de depoimentos de alguns dos militantes recém-chegados ao Chile que foram trocados pelo Embaixador:

Captando entrevistas de alguns dos 70 brasileiros levados àquele país em janeiro daquele ano em troca do embaixador suíço Giovanni Bucher, sequestrado no final de 1970 no Rio de Janeiro pela guerrilha armada da VPR, mostra, entre depoimentos pessoais de sevícias sofridas pelos presos no Brasil, a simulação de torturas encenadas por eles mesmos, como a do pau de arara. O filme, realizado com câmera na mão e de fotografia crua, foi rodado com a colaboração de Saul Landau e Haskell Wexler.

Entre alguns dos entrevistados estão Frei Tito, Maria Auxiliadora Lara Barcelos, Jean Marc van der Weid, ex-presidente da UNE e Nancy Mangabeira Unger, (...) O documentário foi o primeiro documento de denúncia mundial em imagem e som da tortura política no Brasil da ditadura militar. ${ }^{79}$

O impacto dessas denúncias tem uma repercussão internacional, e estará somado a outras iniciativas de denúncia das torturas e atrocidades cometidas pela Ditadura brasileira. No Chile mesmo já haviam sido feitas denúncias dessas torturas, que levam a uma reação do governo brasileiro que busca seguir negando as denúncias, postura essa que os militares seguirão adotando pelo menos até 2014 quando da publicação do relatório da Comissão Nacional da Verdade.

OBS: foi feito um enxugamento em todo este ponto do sequestro no Chile e a RETIRADA RESTANTE DA PARTE SOBRE CENSURA. Buscou-se ser mais sintética na análise, retirando algumas questões correlatas]

\section{CONCLUSÕES}

Como conclusão, nos parece que muitas questões ainda precisam ser investigadas sobre a Ditadura no Brasil. O tema dos sequestros comparece em memórias e em relatos mas pouco se problematizou sobre eles, objetivo central deste artigo. Os sequestros foram uma importante tática de luta contra a Ditadura, ajudaram a salvar a vida de uma centena de pessoas. Mas cobrou também um preço alto daqueles militantes que foram os

\footnotetext{
78 A ênfase no "de fato" se justifica porque foram muitos os casos em que a Ditadura depois de matar os militantes forjou suicídio para amenizar o ocorrido junto à opinião pública.

79 https://pt.wikipedia.org/wiki/Brazil:_A_Report_on_Torture. Consultado em 21/9/2018. O documentário está disponível para ser assistido na Rede www.youtube
} 
responsáveis pelas ações, que foram perseguidos e mesmo mortos. Táticas de Terrorismo de Estado foram sistematicamente usadas contra os envolvidos. O governo chileno recebeu os militantes brasileiros, e o país teve papel importante na disseminação de informações sobre os crimes de lesa humanidade que eram cometidos no Brasil.

Do ponto de vista da tática de luta e resistência, os sequestros de Diplomatas foram muito bem sucedidos, mas foram suspensos devido ao reordenamento da repressão, que ampliou a perseguição, aprimorou seus métodos e promoveu aprimoramento de técnicas de torturas e assassinatos. A documentação diplomática nos trouxe informações que desconhecíamos até então, dado o fato de haver censura na imprensa brasileira. O debate sobre o caráter desta luta de resistência se sobrepõe ao caráter revolucionário dos militantes. Eles acreditavam em uma revolução, mas isso não significa que estavam construindo uma. Essa fase da "guerra Revolucionária" foi pontualmente ganha por eles, mas de um modo defensivo, levando ao reordenamento das forças repressivas que passariam ao ataque sistemático com a Operação Condor externamente a Operação Bandeirantes internamente.

Em um momento histórico difícil como o que o Brasil vive desde 2015, é necessário problematizarmos as histórias das resistências latino-americanas, ainda que a contrapelo da onda revisionista e saudosista da Ditadura. Não se trata de julgar os militantes da luta armada, nem tampouco defender essa tática para a realidade atual, mas é necessário seguir problematizando o Terrorismo de Estado. O presente compilado espera contribuir para o aprofundamento de seu estudo.

\section{Fontes}

\section{Impressas}

Aluízio Palmar, Onde foi que vocês enterraram nossos mortos? Curitiba, Travessa Editores, 2006. Ayrton Centeno. Os vencedores. A volta por cima da geração esmagada pela ditadura de 1964. São Paulo, Geração, 2014.

Carla Rodegher, Um pouco além do concebível: o Chile e a Argentina na memória de um exilado brasileiro. História Unisinos 16(1):93-105, Janeiro/Abril 2012

Carlos Marighella, Manual do Guerrilheiro Urbano, Folheto, 1969.

Carlos Zacarias de Sena Junior, (org) Contribuição à crítica da historiografia revisionista. Rio de Janeiro, Consequência, 2017.

Cid Benjamin, Gracias a la vida: memórias de um militante. Rio de Janeiro, José Olympio, 2013.

Comissão de Familiares de Mortos e Desaparecidos Políticos - IEVE. Dossiê Ditadura: mortos e desaparecidos no Brasil. $2^{a}$ ed. São Paulo, Imprensa Oficial, 2009, 772p.

Demian Melo, (org). A miséria da historiografia: uma crítica ao revisionismo contemporâneo. Rio de Janeiro, Consequência, 2014.

Enrique Padrós, Terrorismo de Estado: reflexões a partir das experiências das Ditaduras de Segurança Nacional. In: GALLO, C. A e RUBERT, S. (orgs). Entre a memória e o esquecimento: estudos sobre os 50 anos do Golpe civil-militar. Porto Alegre, Deriva, 2014.

Enzo Traverso, O passado, modos de usar. Lisboa, Unipop, 2012. 
Fabio Lucas Cruz, Brasileiros no exílio: Argel como local estratégico para a militância política (1065-1979). Tese de Doutorado em História, USP, 2016.

Fernando Gabeira, O que é isso companheiro? São Paulo, Codecri, 1980.

Hatsuo Fukuda, Diógenes o guerrilheiro. Ousar lutar, ousar vencer! Porto Alegre, Evangraf, 2014.

Jacob Gorender, Combate nas trevas. São Paulo, Ática, 1998.

James Green, Revolucionário e gay, Rio de Janeiro, Civilização Brasileira, 2018.

Juliana Ramos Luiz, A ditadura civil-militar diante da crise: os sequestros de diplomatas no Brasil e a análise do processo decisório em política externa. NEIBA, volume IV, n.1, agosto 2015, p. 38.

Jussaramar da Silva, As conexões repressivas no ConeSul (1960-90): Terrorismo de Estado em conexão Internacional, Tese de Doutorado em História, PUCSP, 2017

Liszt Vieira, A busca: memórias da resistência. São Paulo, Hucitec, 2008, p. 20.

Lucileide Costa Cardoso, Revolução e resistência: historiografia e luta armada no Brasil. Revista da FLUP, Porto, IV Série, vol. 4, 2014.

Marcelo Ridenti, Esquerdas armadas urbanas, In: RIDENTI, M e REIS, D. (Orgs) História do marxismo no Brasil, Campinas, EDUNICAMP, 2007.

Marcelo Ridenti, O fantasma da Revolução brasileira. 2a ed. São Paulo, EDUNESP, 2010.

Mario Magalhães, Marighella: o guerrilheiro que incendiou o mundo. São Paulo, Companhia das Letras, 2012.

Noções básicas de Guerra Revolucionária, Coletânea do Estado Maior do Exército, 1963.

Relatório da Comissão Nacional da Verdade, volume 1, Brasília, 2014.

Silvio Da-Rin. Hércules 56: o sequestro do embaixador americano em 1969. Rio de Janeiro, Zahar, 2007.

Sulena Cerbaro e Alessandra Gasparotto, O RS no contexto da Ditadura militar: o caso do "sequestro" do cônsul norte-americano. Anais do II Encontro de Pesquisas Históricas. PPGH/PUCRS, Porto Alegre, 2016, p. 79.

Teresa Cristina Marques, Militância política e solidariedade internacionais. A trajetória política dos exilados brasileiros no Chile e na França. Tese de Doutorado em Ciências Políticas, Porto Alegre, UFRGS, 2011.

Wilma Antunes Maciel, O capitão Lamarca e a VPR: repressão judicial no Brasil, SP, Alameda, 2006.

\section{Fontes de imprensa}

Brazil, a report of torture. https://pt.wikipedia.org/wiki/Brazil:_A_Report_on_Torture. Consulta em 25/6/2019

Jornal do Brasil, 23/2/1975, capa. 